\title{
sciendo
}

\section{Dampening of neurotransmitter action: molecular similarity within the melatonin structure}

\author{
Wynford R. WiLliams \\ Faculty of Life Sciences and Education, University of South Wales, Cardiff, United Kingdom \\ E-mail: Robert.Williams2@southwales.ac.uk
}

Objectives. Melatonin initiates physiologic and therapeutic responses in various tissues through binding to poorly defined MT receptors regulated by G-proteins and purine nucleotides. Melatonin's interaction with other G-protein regulated receptors, including those of serotonin, is unclear. This study explores the potential for the interaction of melatonin with nucleotide and receptor ligand structures.

Methods. The study uses a computational program to investigate relative molecular similarity by the comparative superimposition and quantitative fitting of molecular structures to adenine and guanine nucleotide templates.

Results. A minimum energy melatonin conformer replicates the nucleotide fits of ligand structures that regulate $\mathrm{Ga}_{\mathrm{i}}$ and $\mathrm{Ga}_{\mathrm{q}}$ proteins via serotonin, dopamine, opioid, a-adrenoceptor, and muscarinic receptor classes. The same conformer also replicates the nucleotide fits of ligand structures regulating $\mathrm{K}^{+}$and $\mathrm{Ca}^{2+}$ ion channels. The acyl-methoxy distance within the melatonin conformer matches a carbonyl-hydroxyl distance in guanine nucleotide.

Conclusion. Molecular similarity within the melatonin and ligand structures relates to the established effects of melatonin on cell receptors regulated by purine nucleotides in cell signal transduction processes. Pharmacologic receptor promiscuity may contribute to the widespread effects of melatonin.

Key words: melatonin, GPCR, ion channels, molecular similarity

Melatonin promotes circadian rhythms and physiological effects on systems outside of the CNS through widely expressed receptors (Johnston and Skene 2015; Jockers et al. 2016). Melatonin analogues have considerable therapeutic potential and already find use as adjuvant therapy, for disorders of the eye and gut, hypertension, diabetes, insomnia, in cancer treatment and surgical procedures (Sanchez-Barcelo et al. 2010; Liu et al. 2016). As a derivative of serotonin, melatonin might be expected to initiate some physiologic responses through the regulation of 5-HT receptors. In this respect, melatonin induced hypothermia in rats is abolished by compounds targeting serotonin receptors (Lin and Chuang 2002). Serotonin is a po- tent inhibitor of melatonin binding to human platelet membranes (Vacas et al. 1992). Inhibition of the delayed rectifier $\mathrm{K}^{+}$current in rat hippocampal neurons is attributable to the indole moiety of serotonin and melatonin (Hou et al. 2004). In the gastrointestinal tract, melatonin inhibits the action of serotonin on peristalsis (Bubenik 2008). Agomelatine, an antidepressant naphthalenic analogue of melatonin, has affinity for MT and 5- $\mathrm{HT}_{2 \mathrm{c}}$ receptors (Ettaoussi et al. 2013). Data relating to the effects of melatonin on 5-HT receptors are, however, contradictory. Lucchelli and co-workers (1997) have reported that melatonin does not interact with 5 -HT receptors $\left(5-\mathrm{HT}_{1}-5-\mathrm{HT}_{4}\right)$ in contracting guinea-pig proximal colon. Kamal 
and co-workers (2015), following characterization of functional $\mathrm{MT}_{2}$ and 5- $\mathrm{HT}_{2 \mathrm{c}}$ heteromers in HEK293 cells, have maintained that there is no interaction between the endogenous agonists.

Identical MT ligand-binding characteristics and the limited modelling of melatonin receptors hinder the development of specific therapeutic agents (Chan and Wong 2013). Melatonin $\mathrm{MT}_{1}$ and $\mathrm{MT}_{2}$ receptors couple to the Gi/o family of G-proteins, initiating signal transduction by inhibiting adenyl cyclase, $\mathrm{K}^{+}$ channel opening via $\beta \lambda$ subunits and $\mathrm{Ca}^{2+}$ channel closure (Tosini et al. 2014). Gi/o cell signal transduction processes are common to muscarinic $\left(M_{2}, M_{4}\right)$, $\alpha$-adrenoceptor $\left(\alpha_{2}\right)$, serotonin $\left(5-\mathrm{HT}_{1}\right)$, histamine $\left(\mathrm{H}_{4}\right)$, dopamine $\left(\mathrm{D}_{2}\right)$ and opioid receptors (Southan et al. 2016). $M T_{1}$ receptors also couple to the $G q / G_{11}$ alpha protein and activate phospholipase $\mathrm{C}$ in common with muscarinic $\left(M_{1}, M_{3}, M_{5}\right)$, adrenoceptor $\left(\alpha_{1}\right)$, histamine $\left(\mathrm{H}_{1}\right)$ and serotonin $\left(5-\mathrm{HT}_{2}\right)$ receptors (Southan et al. 2016). Ga links GPCRs to a Rho family GTPase (RhoA) catalysed by p63RhoGEF, a gua- nine nucleotide exchange factor (Lyon et al. 2014). Nitric oxide and guanylyl cyclase are also involved in the anti-adrenergic, cardioprotective and local antinociceptive effects of melatonin (Genade et al. 2008; Hernandez-Pacheco et al. 2008; Yu et al. 2017). Freeradical scavenging and protection of the electron transport chain contribute further to the properties of melatonin (Hardeland 2017).

In this study, factors contributing to the pleiotropic properties of the melatonin molecule are explored in respect of signal transduction mechanisms regulating $\mathrm{G} \alpha$ protein and ion channel receptors. The binding of GTP to G-proteins, initiating GPCR signalling, is used to assay receptor ligand potency (Strange 2010). Previous work has demonstrated the utility of molecular modelling software and established structure-activity data for identifying similarity within receptor ligands in comparison to guanine and adenine nucleotide templates. Ligands of GPCRs and ion channels provide unique fits to nucleotide templates (Williams 2018). The study uses a com-

Table 1

Fitting data of ligand structures superimposed on the ATP template.

\begin{tabular}{|c|c|c|c|c|}
\hline Compounds & Receptor & Fitting points & Inter-atomic distance $(\AA)$ & RMS $(\AA)$ \\
\hline Isoprenaline & $\beta$ & $\mathrm{O} 2 \mathrm{C} 2 \mathrm{~N} 6$ & $0.09,0.15,0.07$ & 0.0035 \\
\hline Melatonin & & $\mathrm{C}_{5} \mathrm{C} 3{ }^{\prime} \mathrm{O} 3$ & $0.01,0.02,0.02$ & 0.0007 \\
\hline Sumanirole & $\mathrm{D}_{2}$ & C2'C1'N9 & $0.03,0.04,0.03$ & 0.0129 \\
\hline Pramipexole & $\mathrm{D}_{3}$ & O3C3'N9 & $0.01,0.16,0.21$ & 0.0153 \\
\hline L750667* & $\mathrm{D}_{4}$ & N6C6N9 & $0.07,0.16,0.11$ & 0.0213 \\
\hline Melatonin & & N6C6N9 & $0.11,0.07,0.17$ & 0.0067 \\
\hline Lisuride $^{*}$ & $a_{2}$ & C8N9C2 & $0.02,0.04,0.04$ & 0.0032 \\
\hline Melatonin & & C8N9C2 & $0.03,0.02,0.05$ & 0.0001 \\
\hline Morphine & $\mu$ & C3'C1'N9 & $0.11,0.05,0.07$ & 0.0011 \\
\hline Melatonin & & N9C1'C3' & $0.04,0.05,0.01$ & 0.0056 \\
\hline SNC80 & $\delta$ & O3C3'N9 & $0.04,0.09,0.13$ & 0.0024 \\
\hline Melatonin & & O3C3’N9 & $0.08,0.08,0.13$ & 0.0106 \\
\hline S14506 & $5-\mathrm{HT}_{1 \mathrm{~A}}$ & C2'C1'N9 & $0.05,0.09,0.03$ & 0.0188 \\
\hline Melatonin & & N9C1'C2' & $0.06,0.14,0.07$ & 0.0370 \\
\hline LY344864 & $5-\mathrm{HT}_{1 \mathrm{~F}}$ & $\mathrm{C}^{\prime} \mathrm{C} 2^{\prime} \mathrm{C} 8$ & $0.08,0.07,0.06$ & 0.0052 \\
\hline Melatonin & & $\mathrm{C}^{\prime} \mathrm{C} 2^{\prime} \mathrm{C} 8$ & $0.09,0.09,0.08$ & 0.0081 \\
\hline Valerenic acid & $5-\mathrm{HT}_{5 \mathrm{~A}}$ & C4N9C3' & $0.14,0.07,0.17$ & 0.0004 \\
\hline Melatonin & & C4N9C3' & $0.02,0.02,0.03$ & 0.0021 \\
\hline
\end{tabular}

*antagonists 
putational program to study molecular similarity within the structures of melatonin, purine nucleotides, GPCR, and ion channel ligands. The research aims are to contribute to a better understanding of melatonin's interaction with so many classes of cell membrane receptor.

\section{Methods}

Compounds representative of receptor ligands regulating $\mathrm{Ga}_{\mathrm{i}}$ and $\mathrm{Ga}$ proteins are listed in Table 1 and Table 2. Molecular formulae of the investigated compounds are listed in IUPHAR (Southan et al. 2016) and Pubchem (http://pubchem.ncbi.nlm.nih. gov) databases. The Nemesis software program (Oxford Molecular version 2.1) is used to build molecular structures, from contents of the program fragment file, and obtain minimum energy conformers by conformational analysis. The ligand structures are minimum energy conformers in an uncharged form. The low energy conformers of ATP and GTP nucleotides are used in a previous setting (Williams 2011). Torsion angles describing the conformer of the melatonin molecule (see Figure 2) are: O6C6N1C10 176

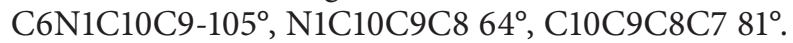
The computational program fits paired molecular structures on a 3 point basis. Fitting points comprise of atoms of similar type and partial charge within ligand and nucleotide structures and are identified with respect to the nucleotide. The fitting sequence of each compound to a nucleotide template is given in Table 1 and Table 2 (reading from left to right). Ligand fitting points are identified in the Figures by colourcoded atoms: carbon-green, nitrogen-blue, oxygenred. Bond order within molecular structures is not shown and the nucleotide structures are cropped, to improve on presentation. The Nemesis program computes goodness-of-fit values in respect of inter-atomic distance at each fitting point and root mean square (RMS) value.

\section{Results}

The fit of the isoprenaline structure to the adenine nucleotide template (Figure 1[1]) demonstrates the potential of this $\beta$-adrenoceptor agonist to promoting cyclisation of ATP by adenyl cyclase; a $\mathrm{G} \alpha_{\mathrm{s}}$ regulated process requiring condensation of the nucleotide 3-hydroxyl and a-phosphate groups. Although melatonin [2] has an equivalent N6-O2 distance to

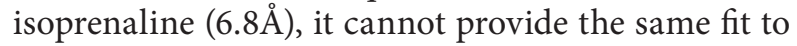
the ATP template. The C5C3'O3 fit [2] places the methoxy group of melatonin in an inhibitory position in regard to the cyclisation of ATP. The other template fits in Figure 1 also relate to structures that oppose nucleotide cyclisation via regulation of $\mathrm{Ga}$. Agonists of dopamine $[3,4]$, morphine $[7,9]$ and serotonin $[13$, $15,17]$ receptors fit with inhibitory groups in proximity to the nucleotide ribose ring hydroxyls. Sumanirole subtends an aminomethyl group from C2; pramipexole, morphine, SNC80 and LY344864 target the 03 hydroxyl. In contrast, antagonists of dopamine and $\alpha_{2}$-adrenoceptor receptors, L750667 [5] and lisuride [11], compete with agonist fitting points on the nucleotide template without interfering with the ribose ring hydroxyls. One conformer of the melatonin molecule replicates the nucleotide template fits of dopamine [6], opioid [8, 10], $\alpha$-adrenoceptor [12] and serotonin ligands $[14,16,18]$. The $\delta$-opiate SNC80 [9] uses the same template fitting points as the D3 agonist pramipexole [4]. D2 and 5-HT $\mathrm{HA}_{1 \mathrm{~A}}$ agonist structures, sumanirole [3] and S14506 [15], also have common fitting points. The fitting values of melatonin match those of other GPCR ligands (Table 1). Goodness of fit values do not exceed $0.20 \AA$ and $0.0400 \AA$ for interatomic and RMS, respectively.

The many different fits of the melatonin conformer to the guanine nucleotide template are given in Figure 2. As exemplified by the M1 agonist structure MCN-A343 [1] some fits of melatonin to the nucleotide template are peripheral [2-6], whereas others $[7-9,11-15]$ show the cyclic rings of melatonin superimposed on those of the nucleotide structure. Fits of the minimum energy melatonin conformer are compared to those given by GPCR ligands (AchM, $\mathrm{a}_{2}$-adrenergic, 5- $\left.\mathrm{HT}_{2}\right)$, ligand-gated $\left(\mathrm{GABA}_{\mathrm{A}}\right.$, glycine, glutamate, $\left.5-\mathrm{HT}_{3}\right)$ and voltage-gated $\left(\mathrm{K}^{+}, \mathrm{Ca}^{2+}\right)$ ion channels. The fits of agonist structures [1, 18, 29] tend to be more peripheral than their corresponding antagonists [16, 19, 30]. The fitting points provided by the acetyl and methoxy groups of melatonin [2] describe a pharmacophore that may relate to the $\mathrm{MT}_{1}$ receptor and an inhibitory effect on GTP cyclisation. Melatonin and GTP O6-O2 distances are respectively $7.8 \AA$ and $7.9 \AA$. Templates 3 and 4, with fitting points on the guanine ring carbonyl group, relate to NMDA [26, 27] and glycine [21] receptors. Melatonin [5] provides a similar fit to diazepam [20] an allosteric promoter at the $\mathrm{GABA}_{\mathrm{A}}$ receptor. Nucleotide templates with superimposed ring systems of melatonin offer a greater choice of fitting points and are more difficult to relate to GPCR and ion channel ligands. Equivalent fitting points are found in the following receptor ligand and melatonin structures: muscarinic $M_{1}[1,16]$ and template 11 (C2N1C6), clonidine [17] and template 8 (N2C2C8), 1-phenyl- 
Table 2

Fitting data of ligand structures superimposed on the GTP template.

\begin{tabular}{|c|c|c|c|c|}
\hline Compounds & Receptor & Fitting points & Inter-atomic distance $(\AA)$ & RMS $(\AA)$ \\
\hline MCN-A343 & M1 & C2N1C6 & $0.07,0,06,0.10$ & 0.0246 \\
\hline Telenzepine ${ }^{\star}$ & M1 & C6N1C2 & $0.02,0.01,0.02$ & 0.0010 \\
\hline Melatonin & & $\mathrm{C} 2 \mathrm{~N} 1 \mathrm{C} 6$ & $0.02,0.04,0.07$ & 0.0103 \\
\hline Clonidine & $\alpha_{2}$ & $\mathrm{~N} 2 \mathrm{C} 2 \mathrm{C} 8$ & $0.12,0.12,0.04$ & 0.0168 \\
\hline Melatonin & & $\mathrm{N} 2 \mathrm{C} 2 \mathrm{C} 8$ & $0.05,0.03,0.07$ & 0.0001 \\
\hline Glutamate & Glu & $\mathrm{C} 8 \mathrm{~N} 9 \mathrm{O} 3$ & $0.06,0.10,0.06$ & 0.0040 \\
\hline Glycine & Gly & O6C6C5 & $0.01,0.04,0.04$ & 0.0050 \\
\hline Kainate & GluK & C8N9C2' & $0.09,0.11,0.03$ & 0.0161 \\
\hline Melatonin & & C8N9C2' & $0.07,0.13,0.06$ & 0.0228 \\
\hline Quinolinic acid & NMDA & O6C6C4 & $0.09,0.05,0.10$ & 0.0055 \\
\hline GABA & $\mathrm{GABA}_{\mathrm{A}}$ & C4C5C6 & $0.09,0.10,0.06$ & 0.0156 \\
\hline Melatonin & & O6N1C5 & $0.08,0.07,0.02$ & 0.0161 \\
\hline Pentylenetetrazole ${ }^{\star}$ & $\mathrm{GABA}_{\mathrm{A}}$ & O6N1C5 & $0.10,0.10,0.16$ & 0.0052 \\
\hline Diazepam & $\mathrm{GABA}_{\mathrm{A}}$ & N7C8C1' & $0.04,0.05,0.02$ & 0.0094 \\
\hline Melatonin & & N7C8C1' & $0.13,0.20,0.10$ & 0.0410 \\
\hline Glycine & Gly & O6C6N1 & $0.02,0.06,0.08$ & 0.0059 \\
\hline Melatonin & & O6C6N1 & $0.04,0.01,0.04$ & 0.0070 \\
\hline TCB-2 & $5-\mathrm{HT}_{2 \mathrm{C}}$ & C6C5N9 & $0.03,0.03,0.02$ & 0.0124 \\
\hline BW723C86 & $5-\mathrm{HT}_{2 \mathrm{~B}}$ & C5C6N2 & $0.03,0.03,0.03$ & 0.0049 \\
\hline AL-37350A & $5-\mathrm{HT}_{2 \mathrm{~A}}$ & $\mathrm{C} 2 \mathrm{C} 4 \mathrm{O} 6$ & $0.09,0.07,0.09$ & 0.0066 \\
\hline Melatonin & & $\mathrm{C} 2 \mathrm{C} 4 \mathrm{O} 6$ & $0.11,0.05,0.10$ & 0.0152 \\
\hline 1-Phenylbiguanide & $5-\mathrm{HT}_{3}$ & N9C4C2 & $0.11,0.17,0.07$ & 0.0359 \\
\hline Melatonin & & $\mathrm{N} 9 \mathrm{C} 4 \mathrm{C} 2$ & $0.03,0.04,0.04$ & 0.0064 \\
\hline Mefenamic acid & $\mathrm{K}_{\mathrm{v}}$ & $\mathrm{C} 6 \mathrm{C} 5 \mathrm{~N} 3$ & $0.04,0.01,0.04$ & 0.0049 \\
\hline Linopirdine & $\mathrm{K}_{\mathrm{v}}$ & $\mathrm{C} 6 \mathrm{C} 5 \mathrm{C} 4$ & $0.01,0.04,0.05$ & 0.0017 \\
\hline Melatonin & & $\mathrm{C} 6 \mathrm{C} 5 \mathrm{~N} 3$ & $0.04,0.03,0.06$ & 0.0024 \\
\hline NS1619 & $\mathrm{K}_{\mathrm{Ca}}$ & C8N9C1' & $0.01,0.03,0.03$ & 0.0073 \\
\hline Melatonin & & C8N9C1' & $0.03,0.03,0.05$ & 0.0068 \\
\hline (R)-BAYK8644 & $\mathrm{Ca}_{\mathrm{v}}$ & C4N9C1' & $0.09,0.15,0.07$ & 0.0378 \\
\hline Melatonin & & C4N9C1' & $0.06,0.07,0.08$ & 0.0205 \\
\hline Melatonin & & $\mathrm{O} 6 \mathrm{C} 6 \mathrm{O} 2$ & $0.12,0.12,0.04$ & 0.0116 \\
\hline Melatonin & & $06 \mathrm{C} 6 \mathrm{Cl}{ }^{\prime}$ & $0.04,0.05,0.05$ & 0.0047 \\
\hline Melatonin & & $\mathrm{C}^{2} \mathrm{C} 8 \mathrm{C} 1{ }^{\prime}$ & $0.11,0.12,0.04$ & 0.0145 \\
\hline Melatonin & & $\mathrm{C} 6 \mathrm{C} 8 \mathrm{O} 2$ & $0.10,0.14,0.05$ & 0.0143 \\
\hline
\end{tabular}

*antagonists 


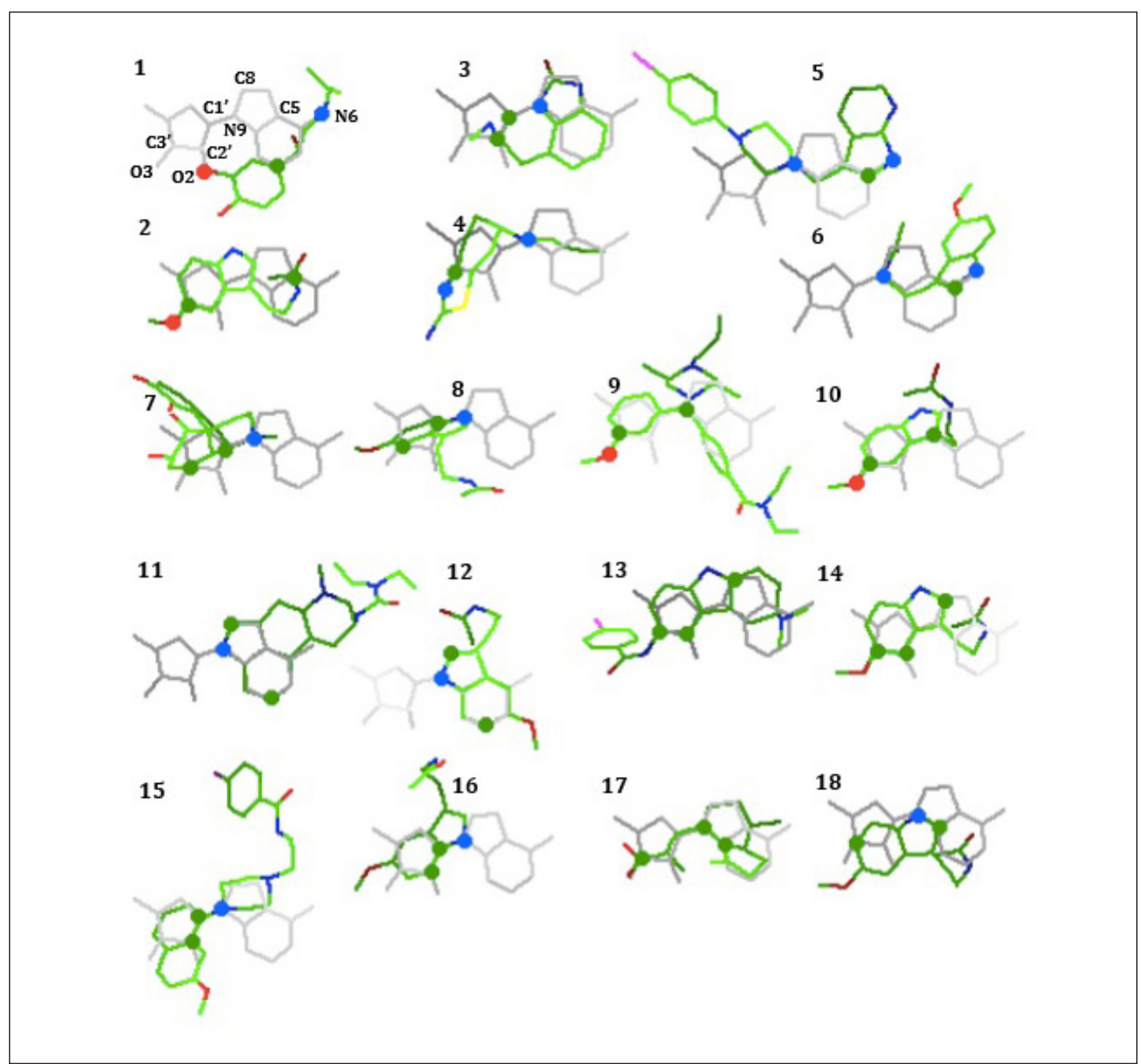

Figure 1. The different fits of the receptor ligand structures and melatonin conformer to the adenine nucleotide template. [1] - isoprenaline, [2] - melatonin, [3] - sumanirole, [4] - pramipexole, [5] - L750667, [6] - melatonin, [7] - morphine, [8] melatonin, [9] - SNC80, [10] - melatonin, [11] - lisuride, [12] - melatonin, [13] - LY344864, [14] - melatonin, [15] - S14506, [16] - melatonin, [17] - valerenic acid, [18] - melatonin. Ligand fitting points are identified by colour-coded atoms: carbon-green, nitrogen-blue, oxygen-red.

biguanide [25] and template 9 (N9C4C2), (R)-BAYK8644 [32] and template 10 (C4N9C1'), pentylenetetrazole [19] and template 12 (O6N1C5), AL-3750A [24] and template 13 (C2C4O6), kainate [33] and template 14 (C8N9C2'), NS1619 [31] and template 15 (C8N9C1'), mefenamic acid [29] and template 7 (C6C5N3). With the exception of the diazepam fit, fitting values of melatonin are as good as those of the specific receptor ligands (Table 2). The fitting values of ligand structures to the GTP nucleotide template do not exceed inter-atomic distance and RMS values of $0.20 \AA$ and $0.0400 \AA$, respectively.

\section{Discussion}

The data obtained in this investigation demonstrate that melatonin replicates pharmacophoric patterns established for class specific receptor ligands fitting to nucleotide templates. Molecular similarity is evident in GPCR and ion channel ligands relative 

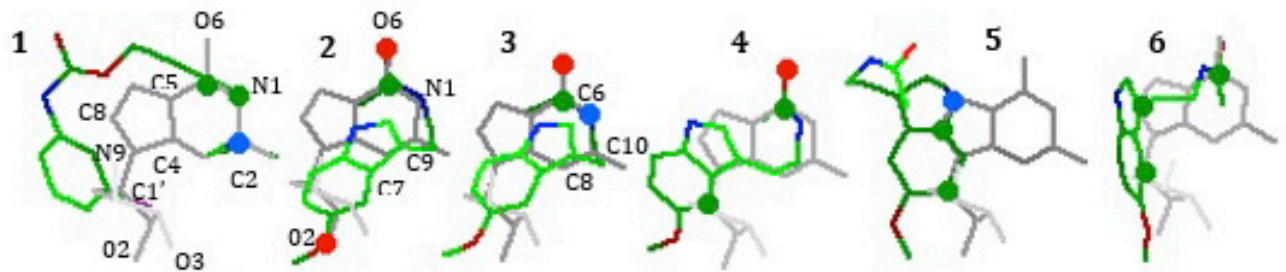

7

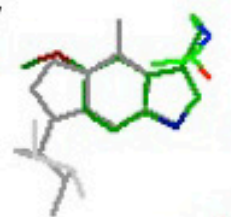

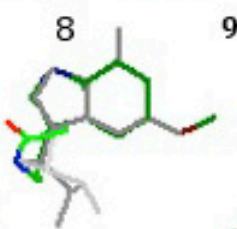

9<smiles>CCC(C)C(C)CC(C)C</smiles><smiles>CC1CC2CCC1CC(C)C2O</smiles>

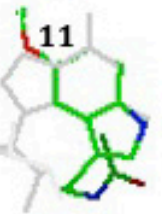

12

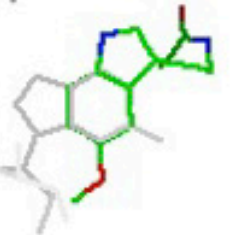

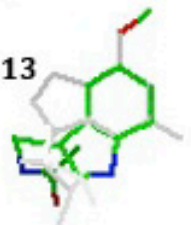

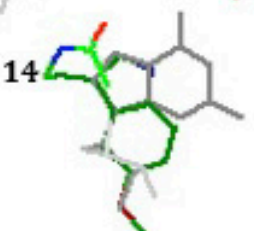

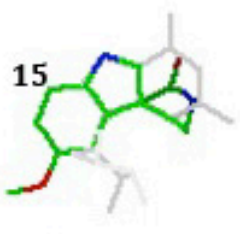

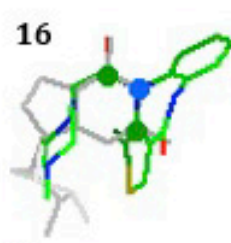

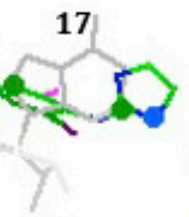<smiles>CCCC1CC[C@@]2(Br)CC(C)CC1C2</smiles>

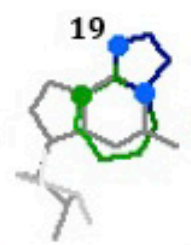
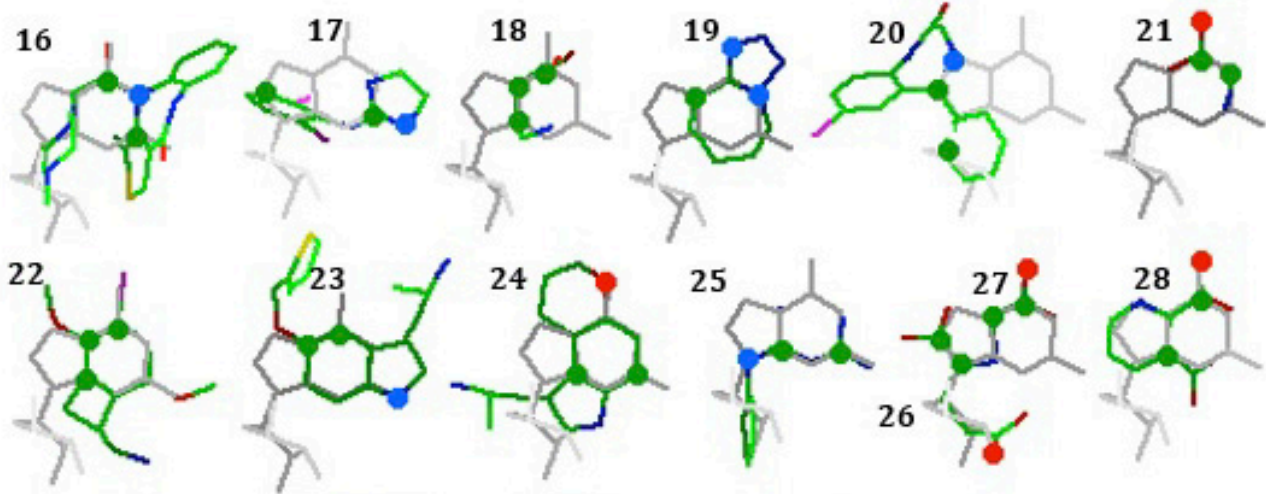

25
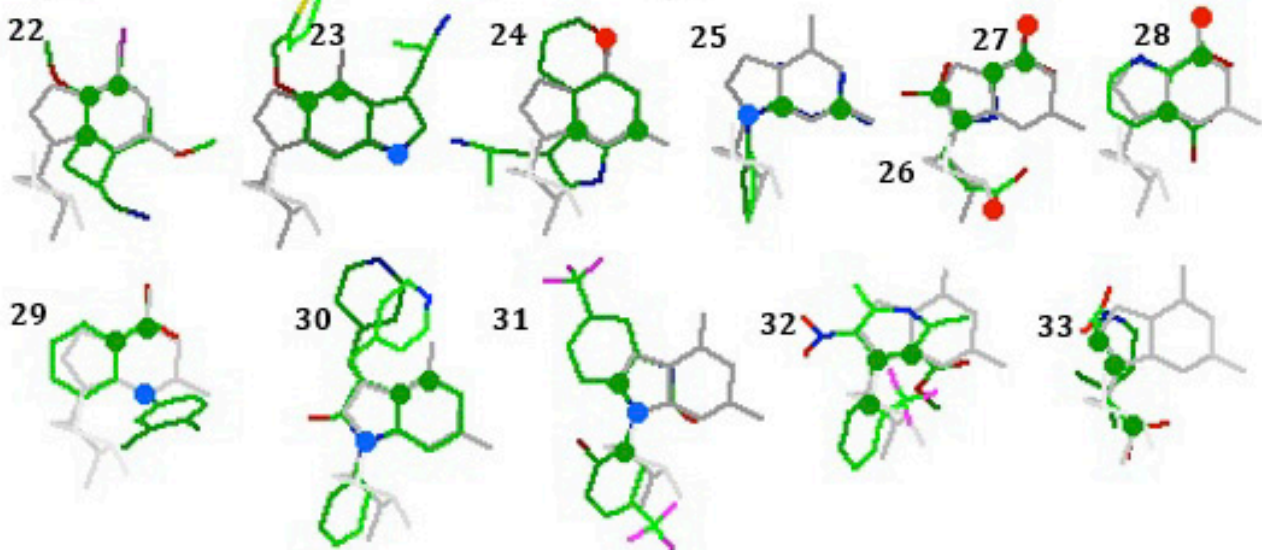

31
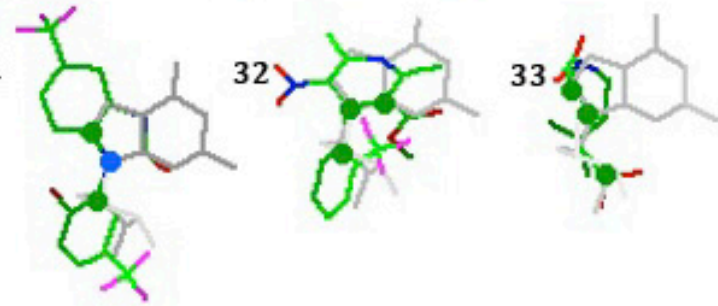

Figure 2. The different fits of GPCR and ion channel ligand structures and melatonin conformer to the guanine nucleotide template. [1] - MCN-A343, [2-15] - melatonin, [16] - telenzepine, [17] - clonidine, [18] - GABA, [19] - pentylenetetrazole, [20] - diazepam, [21] - glycine, [22] - TCB-2, [23] - BW723C86, [24] - AL-37350A, [25] - 1-phenylbiguanide, [26] - glutamate, [27] - glycine, [28] - quinolinic acid, [29] - mefenamic acid, [30] - linopirdine, [31] - NS1619, [32] - (R)-BAY K8644, [33] - kainate. Ligand fitting points are identified by colour-coded atoms: carbon-green, nitrogen-blue, oxygen-red.

to the structures of purine nucleotides that control signal transduction events (Williams 2018). The 3-acylaminoethyl chain and 5-methoxy group are crucial components in the binding of melatonin to $\mathrm{MT}_{1}$ and $\mathrm{MT}_{2}$ receptors, as is the relative distance between the amide group and methoxy group (Chan and Wong 2013). The nucleotide template fits of the melatonin conformer via acyl and methoxy groups, given in Figures 1[2] and 2[2], may relate to $\mathrm{MT}_{1}$ and $\mathrm{MT}_{2}$ receptor pharmacophores. 
In regard to adenine nucleotide, the relative molecular similarity identified within melatonin, dopamine, serotonin, and opioid ligand structures has functional significance, in respect of inhibitory effects on cAMP formation. The anti-nociception pathway elicited by melatonin in rodents is complex with involvement of opioid, serotonin, acetylcholine, dopamine, $\alpha$-adrenoceptor and arginine-NO receptors (Mantovani et al. 2006; Shin et al. 2011). Melatonin reduces hypokinesis and stereotypies induced by D2 ligands and has a synergistic effect with apomorphine in the mouse tail suspension test (Sumaya et al. 2004; Binfare et al. 2010). Melatonin induced hypothermia in rats is significantly reduced by treatment with either a $5-\mathrm{HT}_{2 \mathrm{~A}}$ receptor agonist or $5-\mathrm{HT}_{1 \mathrm{~A}}$ receptor antagonist (Lin and Chuang 2002). In patients, sulpiride and melatonin decrease tinnitus perception by decreasing dopamine activity (Lopez-Gonzalez et al. 2007). Clinical and experimental studies demonstrate that melatonin interacts with the $a_{2}$-agonist clonidine. Clonidine administration decreases urine and plasma melatonin levels in depressed patients and sleeping volunteers (Lewy et al. 1986; Paparrigopoulos et al. 2001). Melatonin impairs contractile responses to clonidine in rat aorta preparations (Weekley 1991). Evidence for melatonin interaction with the cholinergic system arises from studies on seizures, epilepsy and cognitive deficits. Melatonin improves cognitive deficits in mice with scopolamine-induced amnesia and has found use in the clinical treatment of selected patients with epilepsy (Banach et al. 2011; Chen et al. 2018).

The molecular similarity identified within melatonin and adenine nucleotide is also applicable to the structure and function of guanine nucleotide. Interaction of melatonin with the NOS-cGMP pathway results in a vasorelaxing, cGMP dependent, action on rat aorta contracted by 5 -HT and inhibition of NOS activity in mouse colonic neurons (Satake et al. 1991; Storr et al. 2002). The participation of MT receptors in the inhibitory effects of melatonin on NO and cGMP production by bradykinin in rat endothelial cells is, however, contentious (Tamura et al. 2006). Melatonin is reported to enhance GABA and muscimol affinity for the $\mathrm{GABA}_{\mathrm{A}}$ receptor, via a melatonin receptor independent mechanism analogous to benzodiazepine action (Coloma and Niles 1988; Dhanaraj et al. 2004; Cheng et al. 2012). The relevance of melatonin to $\mathrm{GABA}_{\mathrm{A}}$ and glutamate receptor activity is evident in its replication of GABA, pentylenetetrazole, diazepam and glutamate fits to the nucleotide template. Melatonin reduces experimental convulsions initiated by pentylenetetrazole, kainate and compounds acting on NMDA excitatory glutamatergic receptors (Lapin et al. 1998; Banach et al. 2011). Potentiation of the glycine current by melatonin in rat ganglionic cells is attributed to the $\mathrm{MT}_{2}$ receptor (Zhao et al. 2010).

The molecular similarity within guanine nucleotide and melatonin structures extends to the ligands and functional responses of $5-\mathrm{HT}_{3}, \mathrm{~K}^{+}$and $\mathrm{Ca}^{2+}$ channels. Studies on delayed gastric emptying in the rat indicate that exogenous melatonin inhibits $5-\mathrm{HT}_{3}$ receptors on vagal afferent fibres (Kasimay et al. 2005). Melatonin blocks several voltage-gated $\mathrm{K}^{+}$channels and interacts with compounds that open or block $\mathrm{BK}_{\mathrm{Ca}}$ channels (Geary et al. 1998; Varga et al. 2001; Hou et al. 2004). Contractile responses to melatonin observed in rat tail and cerebral arteries are dependent on the antagonism of $\mathrm{BK}_{\mathrm{Ca}}$ channels (Geary et al. 1998; Regrigny et al. 1999). The vasodilation of rat mesenteric artery by melatonin is attributed to direct and indirect (via MT receptors) activation of $\mathrm{BK}_{\mathrm{Ca}}$ channels (Zhao et al. 2017). $\mathrm{Ca}^{2+}$ entry through voltage-gated calcium channels $\left(\mathrm{Cav}_{2.2}\right)$ can be inhibited by physical interaction of the channel with the $\mathrm{MT}_{1}$ receptor (Benleulmi-Chaachoua et al. 2016).

There is substantial evidence within the research literature that MT receptors are not responsible for all physiological effects of melatonin, including studies relating to interaction of the compound with $5-\mathrm{HT}$ ligands and receptors. The data given in this study reveal a molecule multi-functional in respect of interaction with receptor ligand structures: the indole ring of melatonin relates to opiate, $\alpha$-adrenergic, 5 -HT and ion channel ligand structures, whereas the acyl group is relevant to $\mathrm{GABA}_{\mathrm{A}}$, glutamate and glycine function. These receptor-based properties of the indolamine structure may provide a general dampening effect on neurotransmitter activity, an especially useful property for initiating sleep and reducing sleep disturbance. The functional relevance attributable to the molecular similarity may derive from the promotion of ligandinduced conformational changes in the nucleotide structures that switch cell signal transduction events, and extend further to nucleotide-binding domains on protein kinases and several classes of ion channel.

\section{References}

Banach M, Gurdzie E, Jedrych M, Borowicz KK. Melatonin in experimental seizures and epilepsy. Pharmacol Rep 63, 1-11, 2011. 
Benleulmi-Chaachoua A, Chen L, Sokolina K, Sokolina K, Wong V, Jurisca I, Emerit MB, Darmon M, Espin A, Stagljar I, Tafelmeyer P, Zamponi GW, Delagrange P, Maurice P, Jockers R. Protein interactome mining defines melatonin MT1 receptors as integral component of presynaptic protein complexes of neurons. J Pineal Res 60, 95-108, 2016.

Binfare RW, Mantovani M, Budni J, Santos AR, Rodrigues AL. Involvement of dopamine receptors in the antidepressant-like effect of melatonin in the tail suspension test. Eur J Pharmacol 638, 78-83, 2010.

Bubenik GA. Thirty four years since the discovery of gastrointestinal melatonin. J Physiol Pharmacol 59 Suppl 2 , 33-51, 2008.

Chan $\mathrm{KH}$, Wong YH. A molecular and chemical perspective in defining melatonin receptor subtype selectivity. Int J Mol Sci 14, 14385-14406, 2013.

Chen BH, Park JH, Kim DW, Park J, Choi SY, Kim IH, Cho JH, Lee TK, Lee JC, Lee CH, Hwang IK, Kim YM, Yan BC, Kang IJ, Shin BN, Lee YL, Shin MC, Cho JH, Lee YJ, Jeon YH, Won MH, Ahn JH. Melatonin improves cognitive deficits via restoration of cholinergic dysfunction in a mouse model of scopolamine-induced amnesia. ACS Chem Neurosci 9, 2016-2024, 2018.

Cheng XP, Sun H, Ye ZY, Zhou JN. Melatonin modulates the GABAergic response in cultured rat hippocampal neurons. J Pharmacol Sci 119, 177-185, 2012.

Coloma FM, Niles LP. Melatonin enhancement of [3H]-gamma-aminobutyric acid and $[3 \mathrm{H}]$ muscimol binding in rat brain. Biochem Pharmacol 37, 1271-1274, 1988.

Dhanaraj E, Nemmani KV, Ramarao P. Melatonin inhibits the development of tolerance to U-50,488H analgesia via benzodiazepine-GABAAergic mechanisms. Pharmacol Biochem Behav 79, 733-737, 2004.

Ettaoussi M, Sabaouni A, Peres B, Landagaray E, Nosjean O, Boutin JA, Caignard DH, Delagrange P, Berthelot P, Yous S. Synthesis and pharmacological evaluation of a series of agomelatine analogues as melatonin MT1/ MT2 agonist and 5-HT2C antagonist. ChemMedChem 8, 1830-1845, 2013.

Geary GG, Duckles SP, Krause DN, Kraus DN. Effect of melatonin in the rat tail artery: role of K+ channels and endothelial factors. Br J Pharmacol 123, 1533-1540, 1998.

Genade S, Genis A, Ytrehus K, Huisamen B, Lochner A. Melatonin receptor-mediated protection against myocardial ischaemia/reperfusion injury: role of its anti-adrenergic actions. J Pineal Res 45, 449-458, 2008.

Hardeland R. Melatonin and the electron transport chain. Cell Mol Life Sci 74, 38883-38896, 2017.

Hernandez-Pacheco A, Araiza-Saidana CI, Granados-Soto V. Possible participation of the nitric oxide-cyclic GMPprotein kinase G-K+ channels pathway in the peripheral antinociception of melatonin. Eur J Pharmacol 596, 70-76, 2008.

Hou SW, Zheng P, Sun FY. Melatonin inhibits outward delayed rectifier potassium in hippocampal CA1 pyramidal neuron via intracellular indole-related domains. J Pineal Res 36, 242-249, 2004.

Jockers R, Delagrange P, Dubocovich ML, Markus RP, Renault N, Tosini G, Cecon E, Zlotos DP. Update on melatonin receptors: IUPHAR Review 20. B J Pharmacol 173, 2702-2725, 2016.

Johnston JD, Skene DJ. Regulation of mammalian neuroendocrine physiology and rhythms by melatonin. J Endocrinol 226, T187-T198, 2015.

Kamal M, Gbahou F, Guillaume JL, Daulat AM, Benleulmi-Chaachoua A, Luka M, Chen P, Anaraki DK, Baroncini M, Mannoury la Cour C, Millan MJ, Prevot V, Delagrange P, Jockers R. Convergence of melatonin and serotonin (5-HT) signaling at $\mathrm{MT}_{2} / 5-\mathrm{HT}_{2 \mathrm{C}}$ receptor heteromers. J Biol Chem 290, 11537-11546, 2015.

Kasimay O, Cakir B, Devseren BC, Yegen BC. Exogenous melatonin delays gastric emptying rate in rats: role of CCK and 5- $\mathrm{HT}_{3}$ receptors. J Physiol Pharmacol 56, 543-553, 2005.

Lapin IP, Mirzaey SM, Ryzov IV, Oxenkrug GF. Anticonvulsant activity of melatonin against seizures induced by quinolinate, kainate, glutamate, NMDA and pentylenetetrazole in mice. J Pineal Res 24, 215-218, 1998.

Lewy AJ, Siever LJ, Uhde TW, Markey SP. Clonidine reduces plasma melatonin levels. J Pharm Pharmacol 38, 555$556,1986$.

Lin MT, Chuang JI. Melatonin potentiates 5-HT(1A) receptor activation in rat hypothalamus and results in hypothermia. J Pineal Res 33, 14-19, 2002.

Liu J, Clough SJ, Hutchinson AJ, Adamah-Biassi EB, Popovska-Gorevski M, Dubocovich, ML. MT1 and MT2 melatonin receptors: a therapeutic perspective. Annu Rev Pharmacol Toxicol 56, 361-383, 2016.

Lopez-Gonzalez MA, Santiago AM, Esteban-Ortega F. Sulpiride and melatonin decrease tinnitus perception modulating the autolimbic dopaminergic pathway. J Otolaryngol 36, 213-219, 2007.

Lucchelli A, Sanagostino-Barbone MG, Tonini M. Investigation into the contractile response of melatonin in the guinea-pig isolated colon: the role of 5-HT4 and melatonin receptors. Br J Pharmacol 121, 1775-1781, 1997.

Lyon AM, Taylor VG, Tesmer JJG. Strike a pose: Ga complexes at the membrane. Trends Pharmacol Sci 35, 23-30, 2014. 
Mantovani M, Kaster MP, Pertile R, Calixto JB, Rodrigues AL, Santos, AR. Mechanisms involved in the antinociception caused by melatonin in mice. J Pineal Res 41, 382-389, 2006.

Paparrigopoulos T, Psarros C, Bergiannaki JD, Varsou E, Dafni U, Stefanis C. Melatonin response to clonidine administration in depression: indication of presynaptic alpha2-adrenoceptor dysfunction. J Affect Disord 65, 307-313, 2001.

Regrigny O, Delagrange P, Scalbert E, Lartaud-Idjouadiene I, Atkinson J, Chillon JM. Effects of melatonin on rat pial arteriolar diameter in vivo. Br J Pharmacol 127, 1666-1670, 1999.

Sanchez-Barcelo EJ, Mediavilla MD, Tan DX, Reiter RJ. Clinical uses of melatonin: evaluation of human trials. Curr Med Chem 17, 2070-2095, 2010.

Satake N, Oe H, Shibata S. Vasorelaxing action of melatonin in rat isolated aorta; possible endothelium dependent relaxation. Gen Pharmacol 22, 1127-1133, 1991.

Shin DJ, Jeong CW, Lee SH, Yoon MH. Receptors involved in the antinociception of intrathecal melatonin in formalin test of rats. Neurosci Lett 494, 207-210, 2011.

Southan C, Sharman JL, Benson HE, Faccenda E, Pawson AJ, Alexander SP, Buneman OP, Davenport AP, McGrath JC, Peters JA, Spedding M, Catterall WA, Fabbro D, Davies JA, NC-IUPHAR. The IUPHAR/BPS Guide to PHARMACOLOGY in 2016: towards curated quantitative interactions between 1300 protein targets and 6000 ligands. Nucleic Acids Res 44, D1054-D1068, 2016.

Storr M, Koppitz P, Sibaev A, Saur D, Kurjak M, Franck H, Schusdziarra V, Allescher HD. Melatonin reduces nonadrenergic, non-cholinergic relaxant neurotransmission by inhibition of nitric oxide synthetase activity in the gastrointestinal tract of rodents in vitro. J Pineal Res 33, 101-108, 2002.

Strange PG. Use of the GTP $\gamma S\left(\left[{ }^{35} S\right] G T P \gamma S\right.$ and Eu-GTP $\left.\gamma S\right)$ binding assay for analysis of ligand potency and efficacy at G protein-coupled receptors. Br J Pharmacol 161, 1238-1249, 2010.

Sumaya IC, Byers DM, Irwin LN, Dei VS, Moss DE. Circadian-dependent effect of melatonin on dopaminergic D2 antagonist-induced hypokinesia and agonist-induced stereotypes in rats. Pharmacol Biochem Behav 78, 727-733, 2004.

Tamura EK, Silva CL, Markus RP. Melatonin inhibits endothelial nitric oxide production in vitro. J Pineal Res 41, 267-274, 2006.

Tosini G, Owino S, Guillame JL, Jockers R. Melatonin receptors: latest insights from mouse models. Bioessays 36, 778-787, 2014.

Vacas MI, Del Zar MM, Martinuzzo M, Cardinali DP. Binding sites for [3H]-melatonin in human platelets. J Pineal Res 13, 60-65, 1992.

Varga Z, Panyi G, Peter M, Pieri C, Csecsei G, Damjanovich S, Gaspar R. Multiple binding sites for melatonin on Kv1.3. Biophys J 80, 1280-1297, 2001.

Weekley LB. Melatonin-induced relaxation of rat aorta: interaction with adrenergic agonists. J Pineal Res 11, 28-34, 1991.

Williams WR. Relative molecular similarity within purine nucleotide and ligand structures operating on nitric oxide synthetase guanylyl cyclase and potassium $\left(\mathrm{K}_{\mathrm{ATP}}, \mathrm{BK}_{\mathrm{Ca}}\right)$ channels. J Pharm Pharmacol 63, 95-105, 2011.

Williams WR. Cell signal transduction: hormones, neurotransmitters and therapeutic drugs relate to purine nucleotide structure. J Recept Signal Transduct Res 38, 101-111, 2018.

Yu LM, Di WC, Dong X, Li Z, Zhang Y, Xue XD, Xu YL, Zhang J, Xiao X, Han JS, Liu Y, Yang Y, Wang HS. Melatonin protects diabetic heart against ischemia-reperfusion injury, role of membrane receptor-dependent cGMPPKG activation. Biochim Biophys Acta 1864, 563-578, 2017.

Zhao WJ, Zhang M, Miao Y, Yang XL, Wang Z. Melatonin potentiates glycine currents through a PLC/PKC signaling pathway in rat retinal ganglionic cells. J Physiol 15, 2605-2619, 2010.

Zhao T, Zhang H, Jin C, Qiu F, Wu Y, Shi L. Melatonin mediates vasodilation through both direct and indirect activation of BKCa channels. J Mol Endocrinol 59, 219-233, 2017. 